\title{
The Concentrations of Nitrogen Dioxide and Ozone in the Air at Inland and Seashore in Japan
}

\author{
by \\ Kiyoshi Kawamura and Sumiko Sakurai \\ Meteorological Research Institute, Tokyo \\ (Received December 28, 1966)
}

\begin{abstract}
Four separate series of observations of surface $\mathrm{NO}_{2}$ and ozone were made at inland (Sudagai) and seashore (Tomisaki) stations in the central part of Honshu, Japan.

The results of $\mathrm{NO}_{2}$ determination showed a diurnal variation with two maxima respectively at about one hour after sunrise and one to two hours after sunset. The $\mathrm{NO}_{2}$ concentrations on the evenings of fine days were extraordinarily high when the snow around the inland station was gradually melting. On the other hand, the concentrations in maritime air in winter were very low, being $1.5 \mu \mathrm{gNO}_{2} / \mathrm{m}^{3}$ on the average when there was a strong wind with a prevailing SW or SSW-component. At the inland station, the winter and the summer average values were the same, being $3.6 \mu \mathrm{gNO}_{2} / \mathrm{m}^{3}$, and the average values in early autumn and winter at the seashore station were respectively 3.7 and $7.3 \mu \mathrm{gNO}_{2} / \mathrm{m}^{3}$.

At the inland station the average concentrations of ozone during the daytime in winter and summer were respectively 23 and $26 \mu \mathrm{gNO}_{2} / \mathrm{m}^{3}$. These values are lower than those in early autumn and winter at the seashore station, though the altitude of the former station is 701 meters above the sea level. This is explained by taking the topographic situation of the inland station into consideration.
\end{abstract}

\section{Introduction}

The observation of $\mathrm{NO}_{2}$ in unpolluted air has recently been made by several authors at a number of places. According to the observation made on land, the concentration ranges from 2 to $4 \mu \mathrm{gNO}_{2} / \mathrm{m}^{3}$ of the air at NTP. On the other hand, much lower values than $2 \mu \mathrm{gNO}_{2} / \mathrm{m}^{3}$ were obtained by LodGe, MACDonald and Vihman (1960) in the mid-Pacific during two summers. These results suggest that the main source of $\mathrm{NO}_{2}$ in the clean air lies on land. Up to now, there have been two different views on the source of $\mathrm{NO}_{2}$ on a global basis: one is the soil origin hypothesis (MrYA.KE, Kawamura and Sakurai, 1961b and Junge, 1963) and the other considers the main source to be the oxidation of atmospheric $\mathrm{NH}_{3}$ (GEORGII 1963). As to the rate of emission of $\mathrm{NO}_{2}$ from the soil, one of the present authors, KaWAMURA (1964), carried out observations at Tokyo and showed that the observed rate during the daytime ranged from 1 to $4 \times 10^{-3} \mu \mathrm{gNO}_{2} \mathrm{~cm}^{-2} \mathrm{hr}^{-1}$. By these observations, he reconfirmed that a considerable part of $\mathrm{NO}_{2}$ in the clean air originates from the soil. 
The rate of $\mathrm{NO}_{2}$ emission from the soil, as well as the concentration of $\mathrm{NO}_{2}$ in the surface air, may change when the ground is covered with snow. At a seashore station, the $\mathrm{NO}_{2}$ concentration may be influenced by the surface meteorological conditions, especially by the direction of the prevailing wind. To examine these changes in $\mathrm{NO}_{2}$ concentration, the Sudagai Weather Rcporting Station $\left(36^{\circ} 52^{\prime} \mathrm{N}, 139^{\circ} 04^{\prime} \mathrm{E}\right)$, Gunma Pref., and the Tomisaki Weather Station $\left(34^{\circ} 55^{\prime} \mathrm{N}, 139^{\circ} 50^{\prime} \mathrm{E}\right)$, Chiba Pref., were chosen as the observation sites. The former station (an inland one) is in the Mikuni mountain range with an altitude of 701 meters above sea level and is located about $75 \mathrm{~km}$ east of the Japan Sea. The surrounding country is famous as a snowy area. The latter (a seashore station) is, on the other hand, situated on the Pacific shore only about 50 meters off the shore-line. Two separate series of observations on the surface $\mathrm{NO}_{2}$ and ozone were made at the two stations; in winter, 1961 and summer, 1962 at the inland station, and in early autumn, 1963 and winter, 1965 at the seashore. The results of these observations will be described and discussed in this paper.

\section{Methods of observation}

An electro-chemical method (EHMERT, 1952) was used for ozone measurement. The solution for absorbing ozone contains potassium iodide, potassium dihydrogen phosphate, disodium hydrogen phosphate and a small amount of sodium thiosulfate. Two reaction chambers are connected in series and 10 liters of air was passed at a flow rate of $1.21 / \mathrm{min}$. The first chamber was used for a sample and the second for a blank.

Nitrogen dioxide in the air is collected by sucking the air $(1.21 / \mathrm{min}$.) through a fritted glass bubbler (Mryake et al., 1961b) containing Griess-Saltzman's solution (SAltzMAN, 1954) for 1 to 4 hours. The degree of pink coloration is visually compared with standards. It must be noted that in winter, 1961 and summer, 1962 at the inland station collections were done respectively by using two sets of apparatus and an automatic gas sampler manufactured by Kimoto Engineering Company, Ltd., Osaka, Japan. The volume of the air sample was 105 liters on the average, for which the limit of detection was about $0.3 \mu \mathrm{gNO}_{2} / \mathrm{m}^{3}$. Since the determination of $\mathrm{NO}_{2}$ is disturbed by ozone, it is necessary to remove ozone from the air. To do so, a plug (diameter: $0.8 \mathrm{~cm}$ and length: $15 \mathrm{~cm}$ ) of glass wool with a manganese dioxide coating was prepared following Saltzman's procedure, which decomposed about 85 percent of ozone in the air at the flow rate given above.

\section{Results of observation}

The observation of $\mathrm{NO}_{2}$ and ozone in the air at the inland station was made twice: during the periods from 1st to 12 th December, 1961 and from 30th July to 10th August, 1962. The results are shown respectively in Figs. 1 and 2, with the atmospheric pressure and the weather conditions. Two separate series of observation were also made at the seashore station: during the periods from 30th August to 9 th September, 1963 and from 2nd to 16th February, 1965. The results of observation at the seashore station are given respectively in Figs. 3 and 4 , with the surface wind data etc. In these figures, it is noticed that during the daytime there is a 


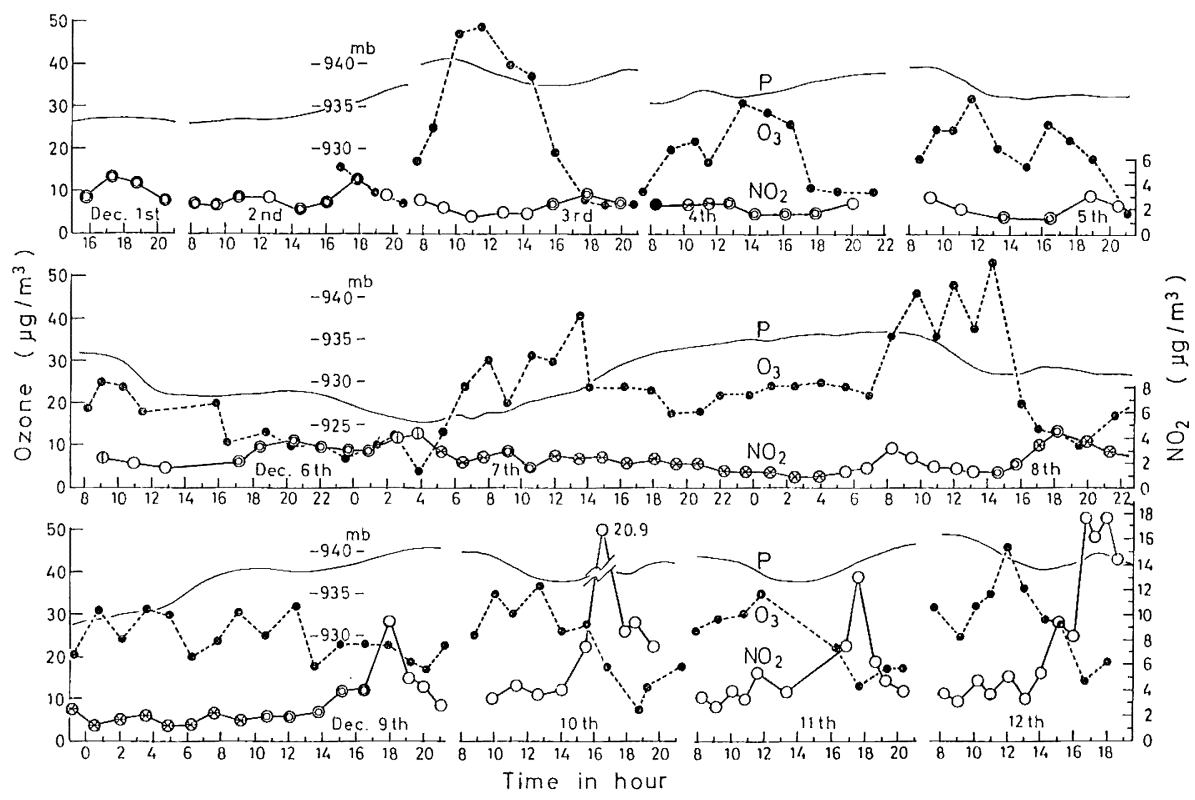

Fig. 1. Concentrations of $\mathrm{NO}_{2}$ and ozone in the air observed at the inland station in winter of 1961.

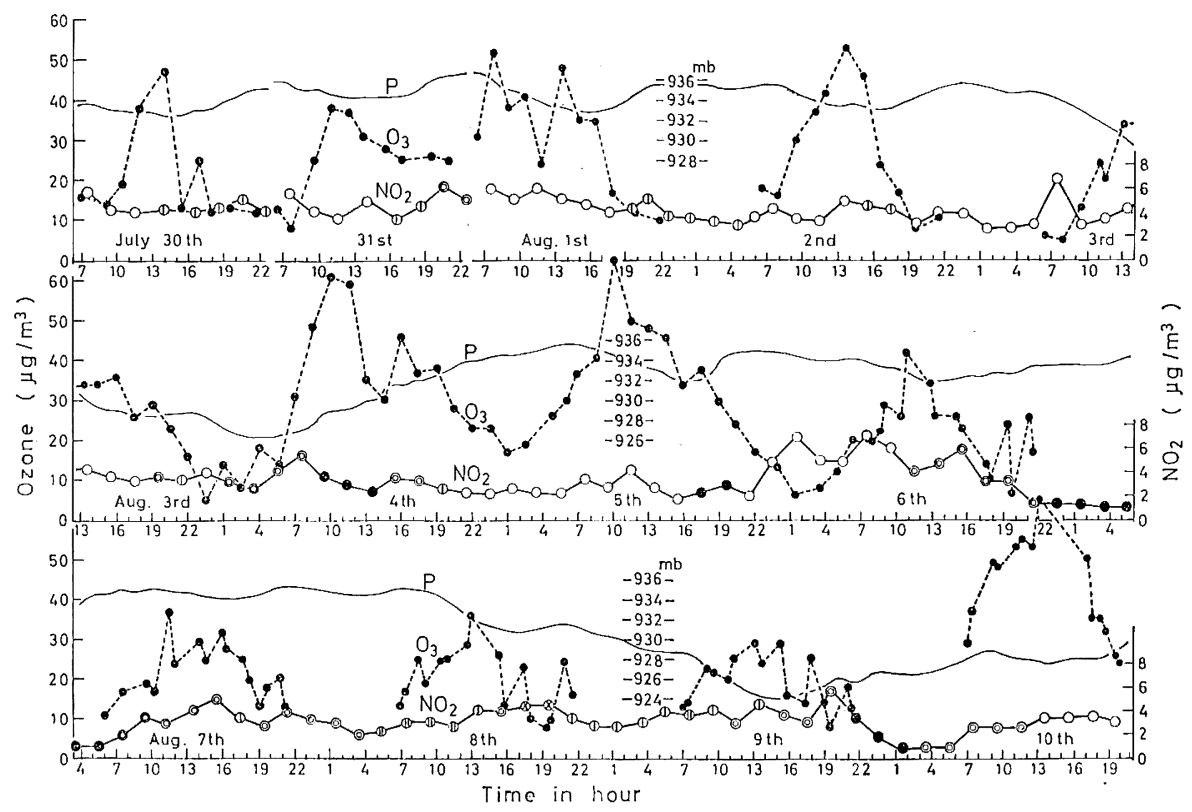

Fig. 2. Concentrations of $\mathrm{NO}_{2}$ and ozone in the air observed at the inland station in summer of 1962 . 


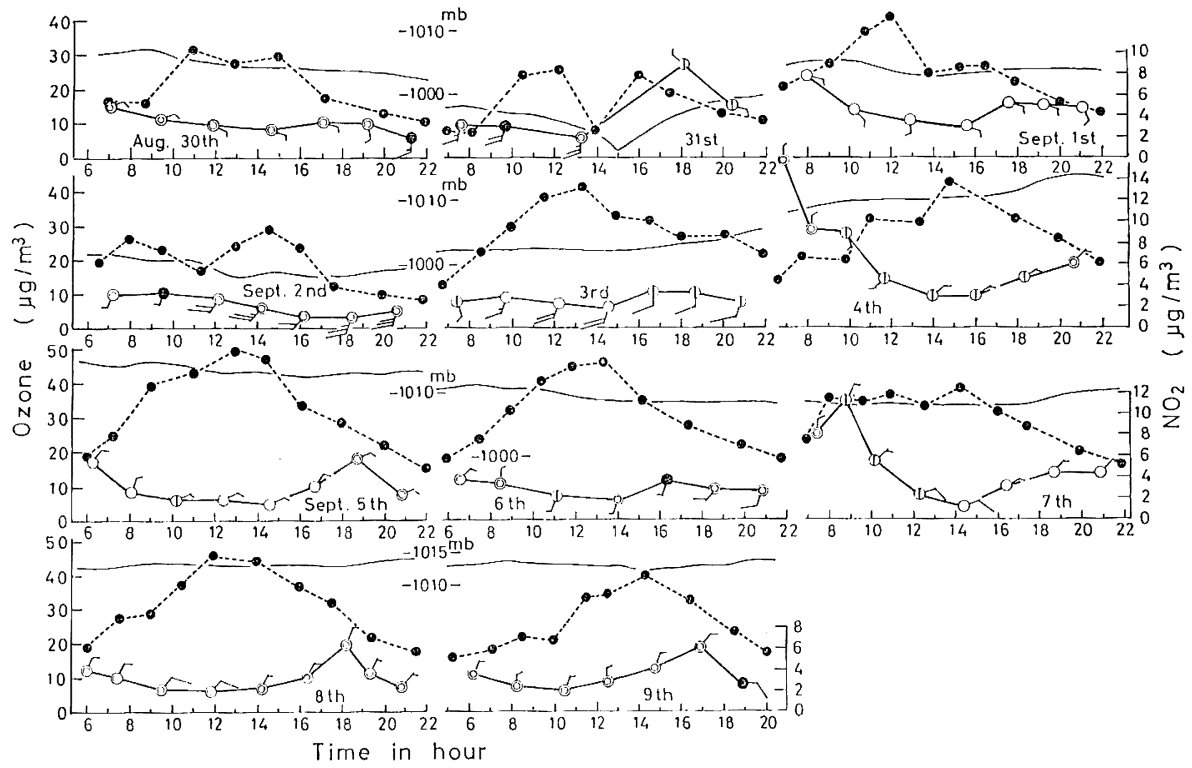

Fig. 3. Concentrations of $\mathrm{NO}_{2}$ and ozone in the air observed at the coastal station in early autumn of 1963.

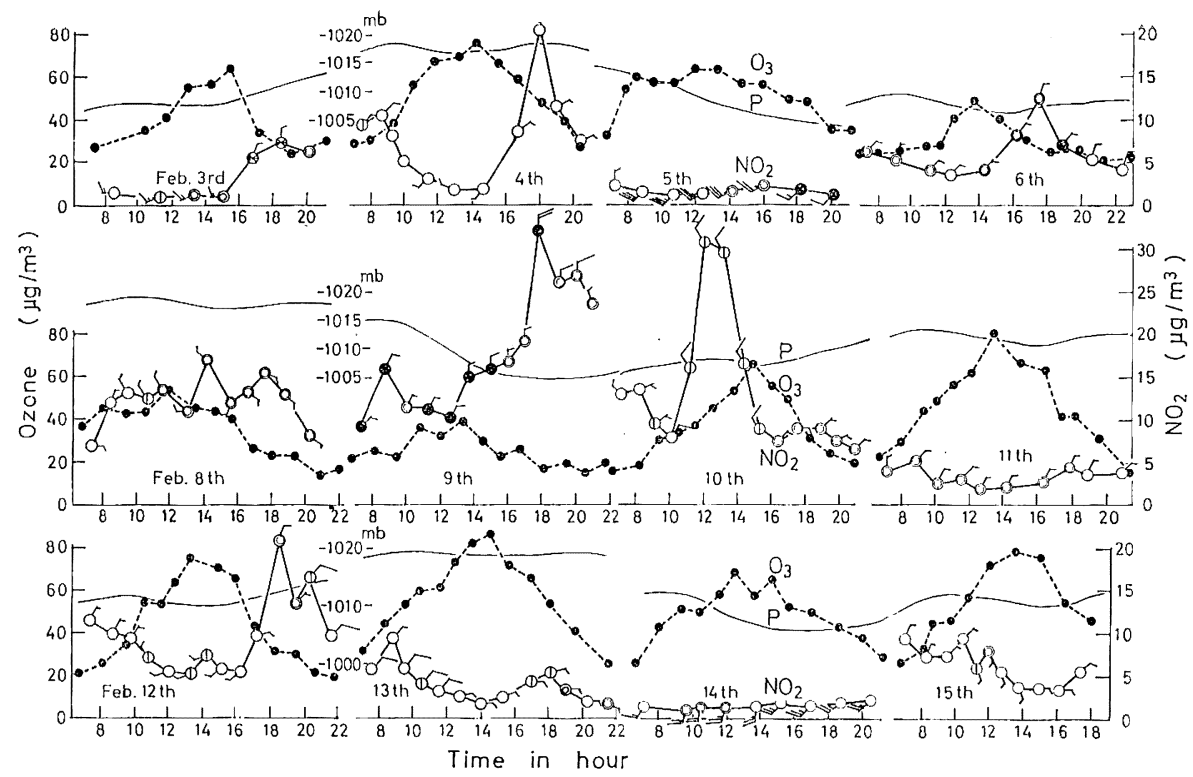

Fig. 4. Concentrations of $\mathrm{NO}_{2}$ and ozone in the air observed at the coastal station in winter of 1965 . 
positive relationship between the ozone concentration and the atmospheric pressure, as pointed out by AuER (1939) and others. The ozone concentration at the inland station in summer generally shows a remarkable diurnal variation with the maximum near the noon as pointed out by many authors, while no similar variation was observed from 7th to 12th December, 1961, when the ground was covered with snow (see Fig. 1). This suggests that the snow cover protects ozone from destruction through chemical reactions with the soil, plants, etc. At the seashore station, on the other hand, the ozone concentration did not show a remarkable nocturnal decrease as was seen at the inland station during the summer. This indicates that under weather conditions at the seashore station the ground air at night is well mixed by turbulence.

The average concentration of ozone during the daytime at the two stations are given in Tab. 1, with those obtained at the western suburb of Tokyo and at the top and the side of Mt. Norikura (Miyake, Kawamura and Sakurai, 1961a and 1961b).

Table 1. Average concentrations of ozone during the day observed at different locations in Japan

\begin{tabular}{|c|c|c|c|}
\hline Location & $\begin{array}{l}\text { Altitude } \\
\quad(\mathrm{m})\end{array}$ & Time & $\begin{array}{c}\mathrm{O}_{3} \\
\left(\mu \mathrm{g} / \mathrm{m}^{3}\right)\end{array}$ \\
\hline Top of Mt. Norikura & 2770 & Sept. 1959 & 58 \\
\hline " & " & Aug.-Sept. 1960 & 30 \\
\hline Side of Mt. Norikura & 1450 & Sept. 1959 & 35 \\
\hline " & $" 1$ & Aug.-Sept. 1960 & 28 \\
\hline Sudagai & 701 & Dec. 1961 & 23 \\
\hline " & " & July-Aug. 1962 & 26 \\
\hline Tomisaki & 12 & Aug.-Sept. 1963 & 30 \\
\hline " & $" 1$ & Feb. 1965 & 46 \\
\hline Tokyo & - & Aug.-Sept. 1958 & 16 \\
\hline " & - & Feb. 1958 and 1959 & 20 \\
\hline
\end{tabular}

The ozone values at Tokyo are only about half of those at Tomisaki. Since the surface air at Tokyo is polluted by various man-made sources, this comparison seems to show that at Tokyo a considerable part of ozone was destroyed through the chemical reactions with contaminants. Although the altitude of the station at Sudagai is 701 meters above the sea, the ozone concentration is lower than that at Tomisaki. The former station is located in the middle of a small basin surrounded by mountains. The average height difference between the station and the tops of the surrounding mountains is about 100 meters and the horizontal distances between them are 600 meters on the average. Because of the topographic situation near the station, the wind speeds during the periods of observation were very low, being mostly below 4 knots. In such calm weather, a thermal stratification of the surface air is liable to occur, which will hinder the downward stream of ozone. The ozone value obtained in early autumn at Tomisaki agrees well with those obtained in summer and early autumn by Teichert (1955) in Germany.

The inland station is a suitable location to observe the surface $\mathrm{NO}_{2}$ which is originated from the soil, because the station is far from towns and is located at 
the bottom of a small basin. On the 4th, 7th, 8th and 9th December, 1961, it was snowy. The $\mathrm{NO}_{2}$ concentrations on the days from the 1 st to about noon of the 9th were low, ranging mostly from 1 to $3 \mu \mathrm{g} / \mathrm{m}^{3}$. On clear days, namely on the $3 \mathrm{rd}$, 5 th and 8th, the $\mathrm{NO}_{2}$ concentration showed a marked diurnal variation with at least one maximum in the evening. On the 8 th December when the observation was done for 24 hours, a morning maximum of $\mathrm{NO}_{2}$ was observed besides the evening maximum. The times of sunrise and sunset at Sudagai during the period of observation were respectively about $06: 40 \mathrm{~h}$ and $16: 30 \mathrm{~h}$, but the actual sunrise and sunset were respectively 08:10h and 14:40h owing to the shadows of the surrounding mountains. Fig. 1 therefore shows that the two maxima occurred respectively a little after sunrise and a few hours after sunset, in agreement with the results obtained at the side of $\mathrm{Mt}$. Norikura by Miyake, Kawamura and Sakurai (1961b) and at Tokyo by Kawamura and Sakurai (1963). The ground was at one time covered by $28 \mathrm{~cm}$ depth of snow on the 9 th, then it gradually melted down to $11 \mathrm{~cm}$ on the 12 th. The weather was fine and calm throughout the days and the concentration of $\mathrm{NO}_{2}$ showed a striking maximum in the evening. Especially, at $16: 24 \mathrm{~h}$ on the 10 th the highest value of $21 \mu \mathrm{gNO}_{2} / \mathrm{m}^{3}$ was observed. On the 10 th when the snow began to melt, about 10 percent of the soil surface around the station was exposed to the atmosphere, and on the 12th about 30 percent. If $\mathrm{NO}_{2}$ is released from the soil as a result of microbiological reactions as in the case of $\mathrm{N}_{2} \mathrm{O}$ (ADEL, 1951 and ARNOLD, 1954), the soil condition as well as the fine and calm weather may be the optimum condition for their activities, which may lead to a high concentration of surface $\mathrm{NO}_{2}$. The occurrences of the morning and evening peaks in $\mathrm{NO}_{2}$ concentration in polluted air were explained by taking account of meteorological conditions, such as the formation of surface temperature inversion at night and the emission of $\mathrm{NO}_{2}$ from the manmade sources (Hamming, MacPheE and Taylor, 1959 and Kawamura and Sakurai, 1963). According to Kawamura (1964), the emission of $\mathrm{NO}_{2}$ from the soil begins with sunrise continuing till late at night, and on a fine day the rate of emission shows its maximum within several hours after sunrise. The diurnal variation of $\mathrm{NO}_{2}$ in the clean air can therefore be explained by replacing the $\mathrm{NO}_{2}$-emission from the man-made sources in urban conditions with that from the soil. In the first half of the period of observation made at the inland station in summer, the weather was relatively fine as is seen in Fig. 2 and the $\mathrm{NO}_{2}$ generally showed a diurnal variation which, however, is smaller than that in winter, while no similar variation was observed in the second half.

In the two separate series of observations at the inland station, we have made the $\mathrm{NO}_{2}$ determination for 24 hours for four consecutive days in winter and for nine days in summer. The average concentrations of $\mathrm{NO}_{2}$ observed during the two periods are given in Tab. 2, in which the results of observation are classified into the day and the night values. The table shows that the night value in winter agrees well with that in summer within the error of observation, while the concentration during the day is higher in summer than in winter.

In contrast to the inland station, there were occasionally windy days at the seashore station. As is seen in Figs. 3 and 4, there was a close relation between the $\mathrm{NO}_{2}$ concentration and the direction of the wind. On days when a strong wind with SW or SSW-component (onshore wind) blew, both ozone and $\mathrm{NO}_{2}$ concentrations were 
Table 2. The average day and night values of $\mathrm{NO}_{2}$ observed on the days when the measurement has been done on a 24 -hour basis

\begin{tabular}{c|c|c}
\hline \multirow{2}{*}{ Time } & \multicolumn{2}{|c}{$\mathrm{NO}_{2}\left(\mu \mathrm{g} / \mathrm{m}^{3}\right)$} \\
\cline { 2 - 3 } & day & night \\
\hline Winter (1961) & 2.0 & 2.7 \\
Summer(1962) & 3.7 & 2.9 \\
\hline
\end{tabular}

low and showed a smaller diurnal variation. This is seen in the data on 31st August, 2nd and 3rd September, 1963 shown in Fig. 3 and on 3rd, 5th and 14th February, 1965 shown in Fig. 4. The average values of the wind speeds and the $\mathrm{NO}_{2}$ concentrations when a strong wind prevailed were respectively 22 knots and $1.5 \mu \mathrm{gNO}_{2} / \mathrm{m}^{3}$ in February and 19 knots and 2. $3 \mu \mathrm{gNO}_{2} / \mathrm{m}^{3}$ in August and September. LODGE, MAcDonALD and Virman (1960) observed the trace substances in the air at the mid-Pacific during two summers and reported that $\mathrm{NO}_{2}$ levels were below the limit of detection (about $2 \mu \mathrm{gNO}_{2} / \mathrm{m}^{3}$ ) in the method used during 94 percent of the time. Our $\mathrm{NO}_{2}$ values obtained on windy days in winter is in accordance with those given by LODGE and others. On days when the weather is fine and the wind with $N$-component (offshore wind) blows, the $\mathrm{NO}_{2}$ concentrations were generally high and showed a diurnal variation as is seen in Fig. 1. The times of sunrise and sunset at Tomisaki during the periods of observation were respectively about $05: 15 \mathrm{~h}$ and $18: 07 \mathrm{~h}$ in early autumn and $06: 33 \mathrm{~h}$ and 17 : $15 \mathrm{~h}$ in winter. The data in Figs. 3 and 4 therefore show that most of the evening maximum in $\mathrm{NO}_{2}$ appeared about one hour after sunset and the morning maximum one hour and a half after sunrise. Therefore, the times of occurrences of these $\mathrm{NO}_{2}$ peaks completely agree with those obtained at the inland station. There are some fishermen's cottages near the observation station and the center of Tateyama city lies beyond the small hills about $10 \mathrm{~km}$ north of the station. In addition, commercial and industrial areas, such as Tokyo and Kawasaki, are located to the north of the station. 'The concentrations of $\mathrm{NO}_{2}$ on the 8th, 9th, 10th and 12th February shown in Fig. 4 were very high and the average value on these days was $13.3 \mu \mathrm{gNO} / \mathrm{m}^{3}$, which was even comparable to the concentrations frequently observed at dawn in the western suburb of Tokyo (Kawamura and Sakurai, 1963). Judging from the daily surface weather maps and the local wind at the observation station, it seems that the higher $\mathrm{NO}_{2}$ values on these days are due to the inflow of the urban air. As was mentioned above, the summer $\mathrm{NO}_{2}$ data at the inland station frequently exhibited no diurnal variation. But, at the seashore station where the air is thermally more unstable than at the inland station, a diurnal variation was generally observed not only in winter but also in early autumn, and the reason for this inconsistent result is unknown.

Fig. 5 shows the results of observation of the tropospheric $\mathrm{NO}_{2}$ made at different continental and maritime locations by the present authors and other investigators. In the figure the graph on the left is arranged in the order of the height of observation stations and that on the right is in the order of the degree of pollution. Both the summer and winter average values at Sudagai were $3.6 \mu \mathrm{gNO}_{2} / \mathrm{m}^{3}$, while at Tomisaki where the air seems to be frequently contaminated by the inflow of the urban air, the concentration in winter was considerably higher than that in early autumn. Although the winter observation at Sudagai showed an extraordinary high concentration of $\mathrm{NO}_{2}$ in the latter half of the observational period, the concentrations on 
Fig. 5. Average concentrations of tropospheric $\mathrm{NO}_{2}$ observed at various continental and maritime locations

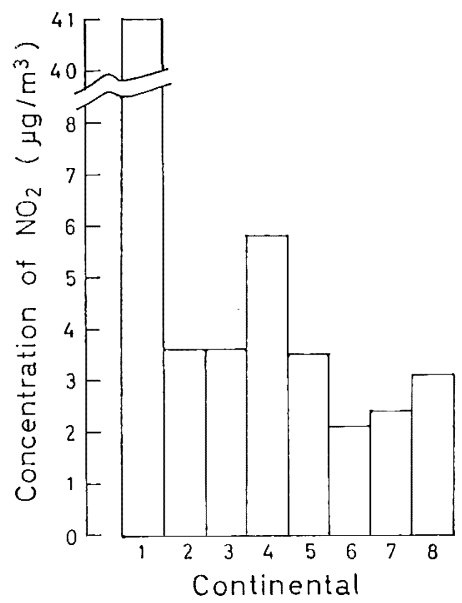

1. Tokyo

2. Sudagai

3.

4. Kleiner Feld- (Nov.-Jan.) 800m berg

5. Side of Mt. (Aug.-Sept.) 1450m Norikura

6. St. Moritz

7. Top of Mt. Norikura

8. Zugspitze

9. Tomisaki

10.

11. Florida

12. Hawaii
(Sept.-Aug.)

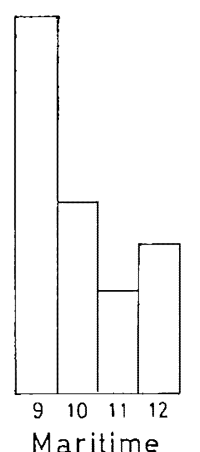

Kawamura and Sakurai (1963)

Present paper Georgii (1960)

Miyake and others (1961b)

(Aug.) 1800m Georgii (1960)

(Aug.-Sept.) 2770m Miyake and others (1961b)

(Aug.) 3000m Georgii (1960) (Feb.) Present paper (Aug.-Sept.) (July-Aug.) (Oct.) the first half (from Ist to 6th December) when the ground was not covered with snow were generally low, and its average was $2.4 \mu \mathrm{g}$ $\mathrm{NO}_{2} / \mathrm{m}^{3}$. This is two-thirds of the summer average value at the same station. If we compare $\mathrm{NO}_{2}$ in the clean air in different seasons when the soil is not covered with snow, the above result seems to suggest that the concentration is higher in summer than in winter. Fig. 5 does not necessarily show that except for the data at Tokyo, the $\mathrm{NO}_{2}$ concentration decreases with the increasing height of the observation station. Particularly, the values at the last three continental stations show a trend of variation which is contrary to expectation, though all of these observations were made in the same season of year. Since there is an ascending air current along the mountain slope caused by the solar radiation, the observed data at a mountain station generally show the concentration of $\mathrm{NO}_{2}$ in the lower air rather than in the air at the level of the station. The values shown in Fig. 5 therefore do not necessarily represent a true vertical profile. The $\mathrm{NO}_{2}$ values at Florida and Hawaii are nearly equal to those at St. Moritz, the top of Mt. Norikura and the Zugspitze, and are a little higher than the values obtained in the mid-Pacific by LODGE et al. (1960) as well as at Tomisaki in winter when the maritime air flows into the observation site. This suggests that the air at Florida and Hawaii is subject to the influence of $\mathrm{NO}_{2}$ which originates in the soil.

\section{Concluding remarks}

1. It is reconfirmed that the $\mathrm{NO}_{2}$ concentration in the unpolluted air exhibits a diurnal variation which is similar to that obtained for the polluted air at Tokyo. This supports our previous view that the main source of the surface $\mathrm{NO}_{2}$ is the soil.

2. From the $\mathrm{NO}_{2}$ data obtained by the present authors and other investigators, it is estimated that the concentration in the maritime air is about $2 \mu \mathrm{gNO} / \mathrm{m}^{3}$ at the highest. 
3. The concentration of $\mathrm{NO}_{2}$ in the clean air is a little higher in summer than in winter.

4. From a series of ozone observations by Miyake and the present authors carried out up to now at various locations in Japan, it is concluded that the concentration is strongly affected by the local conditions.

Acknowledgments-The authors wish to express their hearty thanks to Dr. Y. Mryake, Director of the Geochemical Laboratory of the Meteorological Research Institute, for his guidance and encouragement throughout this work. Thanks are also due to the colleagues of the authors' laboratory for their valuable advice and discussions, and to the staff-members of the Sudagai Weather Reporting Station and the Tomisaki Weather Station, for their kind help during the observations.

\section{References}

Ader, A., 1951: Atmospheric nitrous oxide and the nitrogen cycle. Science, 113, 624-625.

Arnocb. P., 1954: Losses of nitrous oxide from soil. J. Soil Sci., 5, 116-127.

AUER, R., 1939: Über den täglichen Gang des Ozongehalts der bodennaher Luft. Gerl. Beitr. Geophys., 54, 137-145.

Eнmerт, A., 1952: Gleichzeitige Messungen des Ozongehalts bodennaher Luft an mehreren Stationen mit einem einfachen absoluten Verfahren. J. Atmosph. Terr. Phys., 2, 189-195.

Georgin, H.W., 1960: Untersuchungen über atmosphärische Spurenstoffe und ihre Bedeutung für die Chemie der Niederschläge. Geofis. pura e appl., 47, 155-171.

1963: Oxides of nitrogen and ammonia in the atmosphere. Journ. Geophys. Res., 68, 3963-3970.

HAMming, W.J., R.D. MAOPhes and J.R. TAYLoR, 1959: Contaminant concentration in the atmosphere of Los Angeles County. A paper presented at the Air Pollution Control Association 52nd Annual Meeting, Calif.

Junge, C.E., 1956: Recent investigations in air chemistry. Tellus, 8, 127-139.

1957: Chemical analysis of aerosol particles and of gas traces on the island of Hawaii. Tellus, 9, 528-537.

1963: Air chemistry and radioactivity. Academic Press, New York and London. p.86.

Kawamura, K. and S. Sakurai, 1963: The content of the atmospheric nitrogen dioxide in the suburb of Tokyo. Papers Met. Geophys., 14, 214-224.

KaWamURA, K., 1964: Studies on the atmospheric ozone and nitrogen dioxide. Geophys. Mag., $32,153-204$.

LODGE, J.P., A.J. MACDonatid and E. VIHMAN, 1960: A study of the composition of marine atmospheres. Tellus, 12, 184-187.

Miyaige, Y., K. Kawamura and S. Sakurai, 1961a: Ozone and nitrogen dioxide in an urban atmosphere. Pap. Met. Geophys., 12, 75-84.

. 1961b: Atmospheric ozone and nitrogen dioxide observed at Mt. Norikura. Pap. Met. Geophys., 12, 310-317.

Saldzman, B.E., 1954: Colorimetric microdetermination of nitrogen dioxide in the atmosphere. Anal. Chem., 26, 1949-1955.

Taichert. F., 1955: Vergleichende Messung des Ozongehaltes der Luft am Erdboden und in 80m Höhe. Zeitschr. Met., 9, 21-27. 


\title{
須田貝および富崎で観測した大気二酸化窒素およびオゾンの濃度
}

\author{
川村清 ·脮井澄子
}

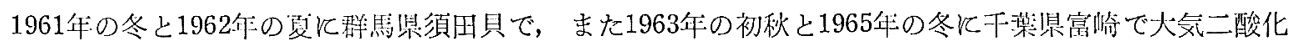

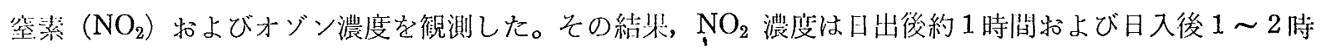

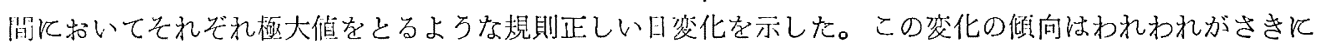

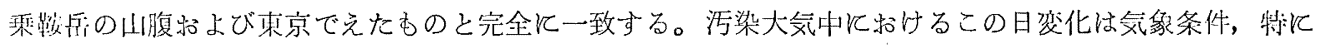

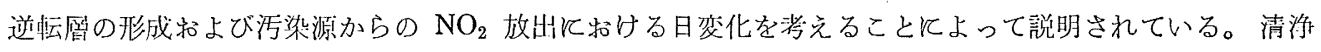
な大気中での場合は人工的発生源のかわり飞われわれが 提出した土じょうからの $\mathrm{NO}_{2}$ 放出説をとり入れ ることによって説明できるだろう。

須田具の観测点近くの積珰が溶けている日の夕方に高濃度の $\mathrm{NO}_{2}$ が钼测された。大気に露出した地面

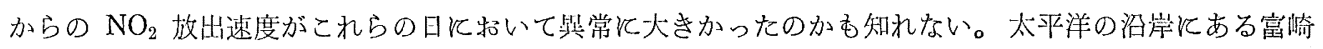

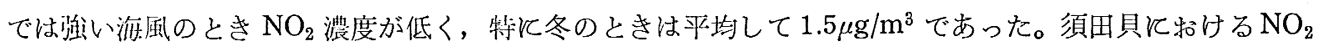

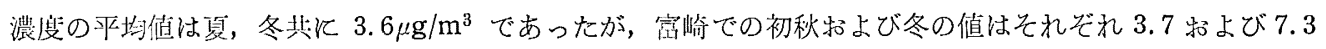
$\mu \mathrm{g} / \mathrm{m}^{3}$ であった。富崎の冬飞打ける值は大きいが，これは観测点北方にある諸都市の污染された空気が流 入したためと考えられる。

須田貝の観测点は海拔 701m にありながら富䐀飞怙けるよりあオゾン濃度は低かった。これは前者が小 さな盆地接萱しているため, 風が弱く, 従ってじょう乱等による大気の上下混合が不活発なために生じ たと溚えられる。 